\title{
Erratum to: individual-level changes in self-rated health before and during the economic crisis in Europe
}

Dawit Shawel Abebe ${ }^{1 *}$, Anne Grete Tøge ${ }^{2}$ and Espen Dahl²

Unfortunately, after publication of this article [1], it was noticed that there errors within the article. In the Background and Conclusion sections, the two uses of the word "casual" was intended to be "causal". In the Results section, the text "elven countries" should instead read "eleven countries".

\section{Author details \\ ${ }^{1}$ NOVA, Oslo and Akershus University College, P.O. Box: 4St. Olavs plass, Oslo NO-0130, Norway. ${ }^{2}$ Faculty of Social Sciences, Oslo and Akershus University College, Oslo, Norway.}

Received: 14 March 2016 Accepted: 14 March 2016

Published online: 23 March 2016

\section{Reference}

1. Abebe DS, Tøge AG, Dahl E. Individual-level changes in self-rated health before and during the economic crisis in Europe. Int J Equity Health. 2016;15:1. doi:10.1186/s12939-015-0290-8.

\footnotetext{
* Correspondence: dawit.s.abebe@nova.hioa.no

'NOVA, Oslo and Akershus University College, P.O. Box: 4St. Olavs plass, Oslo NO-0130, Norway
}

Full list of author information is available at the end of the article

Submit your next manuscript to BioMed Central and we will help you at every step:

- We accept pre-submission inquiries

- Our selector tool helps you to find the most relevant journal

- We provide round the clock customer support

- Convenient online submission

- Thorough peer review

- Inclusion in PubMed and all major indexing services

- Maximum visibility for your research

Submit your manuscript at www.biomedcentral.com/submit

\section{() Biomed Central}

